УДК 94 (571.1)

ББК 63.3(253.3)

\title{
Деятельность Семиреченского областного статистического комитета по сохранению историко-культурного наследия в регионе в конце XIX - начале XX в.
}

\author{
B.A. Cкопа
}

Алтайский государственный педагогический университет (Барнаул, Россия)

\section{The Activities of the Semirechye Regional Statistics Committee on the Preservation of Historical and Cultural Heritage in the Region in the Late $19^{\text {th }}-$ Early $20^{\text {th }}$ Century}

V.A. Skopa

Altai State Pedagogical University (Barnaul, Russia)

На основе архивного материала и опубликованных источников рассматривается деятельность Семиреченского областного статистического комитета в конце XIX - начале XX в. по сохранению историко-культурного наследия в регионе посредством музейной деятельности. Анализ выявленных источников позволил реконструировать отдельные направления в работе музея по формированию коллекций и самостоятельных экспозиций.

Музей первоначально состоял из пяти отделов: физико-географического, этнографического, сельскохозяйственного, кустарно-промышленного и археологического. С конца XIX в. экспонаты музея пополнялись в основном за счёт пожертвований частных лиц, уездных начальников, учебных заведений, местных и центральных учреждений. Первыми меценатами были члены комитета Э.О. Баум и К.А. Ларионов. Они пожертвовали свои личные коллекции. Значимость формируемых музейных коллекций и экспозиций в регионе оценивалась весьма высоко.

С целью развития и пополнения коллекций музея члены статистического комитета организовывали и проводили научные экспедиции. В начале $\mathrm{XX}$ столетия на территории Семиречья с научной целью при непосредственном участии членов комитета работали экспедиции профессора Томского университета В.В. Сапожникова, Балхашская экспедиция действительного члена ИРГО Л.С. Берга и экспедиция Императорского Санкт-Петербургского ботанического сада.

Ключевые слова: региональная история, Семиречье, статистический комитет, музейная коллекция, экспозиция.

DOI 10.14258/izvasu(2019)6-07
On the basis of archival material and published sources, the author examines the activities of the Semirechye Regional Statistics Committee in the late $19^{\text {th }}-$ early $20^{\text {th }}$ century the preservation of historical and cultural heritage in the region by means of Museum activities. The analysis of the identified sources allowed to reconstruct certain directions in the Museum's work on the formation of collections and independent expositions.

The Museum originally consisted of five departments: physical and geographical, ethnographic, agricultural, handicraft and archaeological. Since the end of the $19^{\text {th }}$ century, the exhibits of the Museum were replenished mainly by donations from individuals, County chiefs, educational institutions, local and central institutions. The first philanthropists were the Committee members E.O. Baum and K.A. Larionov. They donated their personal collections. The need and importance of the Museum collections and expositions being formed in the region was assessed very highly.

In order to develop and replenish the Museum's collections, the Committee members organized and conducted scientific expeditions. In the early $20^{\text {th }}$ century, with a scientific purpose with the direct participation of the Committee members Professor of Tomsk University V.V. Sapozhnikova, Balkhash expedition member of the Russian Geographical Society L.S. Berg and the expedition of the Imperial St. Petersburg Botanical Garden worked on the territory of Semirechye.

Key words: regional history, Semirechye, statistics committee, museum collection, exposure. 
В отечественной историографии отдельные проблемы организации и развития региональных музеев вызывают научный интерес: с одной стороны, переосмысление конкретных событий или процессов с учетом выявленных исторических источников, с другой - устремлением более четко реконструировать ряд важнейших мероприятий, являющихся основополагающими в процессе социокультурного развития и изучения региона.

В современной историографии вклад статистических учреждений в развитие музейной деятельности, а вместе с тем и проблемы сохранения культурного наследия рассматриваются в работах Д. Исламовой, Е.В. Игумнова, В.А. Аленовой [1-3]. Становление статистического комитета в Семиречье и организация деятельности его служащими по сохранению историко-культурного наследия в регионе представлена в исследованиях С.А. Урашева, С.К. Игибаева $[4,5]$. Авторы описывают процесс становления статистического учреждения в регионе и стремятся показать его вклад в оформление первых музейных коллекций. В то же время остается нераскрытой проблема оформления музея и формирование его первых коллекций при статистическом комитете в Семиреченской области как национальной окраине Российской империи.

Актуальность заявленой проблемы заключается в анализе и переосмыслении процесса становления музея при Семиреченском статистическом комитете как центра по сохранению историко-культурного наследия в регионе и возможности использования этих сведений в современных исторических исследованиях по проблемам локальной истории культуры.

Научная новизна исследования определяется тем, что на основе выявленного материала предпринята попытка дать обоснованную оценку деятельности Семиреченского областного статистического комитета по сохранению историко-культурного наследия в регионе.

Целью данной статьи является историческая реконструкция процесса становления музея при статистическом комитете Семиреченской области.

Источниковой базой исследования являлись как опубликованные источники, так и архивные материалы [6-13]. К числу опубликованных источников можно отнести отчеты секретарей Семиреченского областного статистического комитета. Архивные документы были выявлены в Центральном государственном архиве Республики Казахстан (Алматы). Анализ систематизированных исторических документов позволил комплексно подойти к рассматриваемой проблеме с учетом особенностей развития региона, проанализировать механизмы становления музея при областном статистическом комитете.

Организация музея при статистическом комитете относится к концу XIX в. Его открытие являлось значительной страницей в истории культуры горо- да Верного и всего Семиречья. В письме в Верненскую городскую управу от 18 ноября 1902 г. отмечалось: «В 1897 году среди членов Семиреченского областного статистического комитета возникла мысль учредить при нем областной музей» [6, л. 6-7]. В письмах-обращениях организаторы Семиреченского музея сообщали, что в состав музейных экспозиций «войдут представители флоры и фауны Семиречья, а также образцы горных пород...» $[6$, л. 8]. Эти письма были разосланы лицам, которые добровольно, из любви к окружающей природе занимались вопросами, связанными с изучением Семиречья. Помимо того, просьбы об оказании помощи в сборе коллекций члены комитета направляли в Санкт-Петербургский университет, в Санкт-Петербургский горный институт, в ЗападноСибирский отдел Русского географического общества и другие организации [6, л. 58-59]. Эти обращения нашли широкий отклик, и в музей стали поступать бесценные экспонаты. Впоследствии Н.Н. Пантусов, один из активнейших организаторов музея, писал: «Уже в 1898 г. число пожертвованных для областного музея предметов оказалось настолько значительным, что встретилась необходимость в найме для музея сколь-нибудь соответствующего помещения», а это было не так-то просто сделать создателям музея [7, л. 3].

Организаторы музея при создании этого культурно-просветительного учреждения ставили две задачи, которые должны решаться: научную и практическую. В отчете секретаря отмечалось, что организация музея «является одною из наиболее существенных и важных культурных нужд, удовлетворение которых в настоящее время, бесспорно, должно быть признано неотложным» $[8$, л. 19]. Затем отмечалось: «...научные задачи должны состоять, с одной стороны, в естественно-историческом изучении области, с другой в распространении естественно-исторических знаний среди местного населения. Практические задачи музея таковы: а) возможное содействие к разрешению вопросов; б) содействие к разрешению вопросов, относящихся к промышленности края; в) разрешение вопросов, имеющих отношение к народной школе» [9, л. 12]. Музей, по замыслу его учредителей, должен был состоять из пяти отделов: физико-географического, этнографического, сельскохозяйственного, кустарно-промышленного и археологического. По мере увеличения экспонатов отделы создавали коллекции и отдельные экспозиции.

Физико-географический отдел включал все вышедшие в свет географические карты Семиреченской области; геологическую карту Семиреченской области; таблицу главнейших горных массивов; протяжение рек Семиречья, систему орошения, название и приблизительное пространство занимаемой ими земли; размеры озер; фотографические снимки всех типичных местностей Семиречья, представителей флоры и фауны; почвы, образчики их с опре- 
делением их состава, образцы минеральных пород Семиреченской области; таблицы температуры, давления, ветров, даты вскрытия и замерзания рек, календарь флоры [6, л. 10].

Этнографический отдел включал в себя таблицы народностей, населяющих Семиречье, и их распределение: по племенам, религиям, сословиям. Отдельно по рисункам и печатным источникам были представлены модели жилищ, предметы одежды, обуви, домашней утвари, игрушек, обычаи [9, л. 10-11]

Одним из самых крупных являлся сельскохозяйственный отдел, который включал следующие подразделы: земледелие (образцы культивируемых почв, сорта хлебных растений, модели употребляемых земледельческих орудий); скотоводство (рисунки или чучела домашних животных, образцы шерсти и других продуктов скотоводства, растения, употребляемые в пищу домашними животными, методы обработки и переработки продуктов скотоводства); садоводство (название сортов диких и культурных плодов деревьев и образцы их плодов, образцы сушеных плодов); огородничество (огородные культуры); пчеловодство (модели ульев, продукты пчеловодства: мед, воск, экономическое значение пчеловодства в жизни населения области, каталог медоносных растений, список крупных пчеловодов, таблицы распределения пасек по области); хмелеводство (сорта дикого и культурного хмеля, устройство хмельников (в моделях)); шелководство (тутовое дерево - его рисунок и образцы листьев, коконы и шелк местного производства, образцы шелковых местных материй; кормовые и промысловые растения: их названия и сушеные экземпляры, виды горного и степного сена) [6, л. 12].

Кустарно-промышленный отдел включал в себя образцы кустарной промышленности из различных местностей Семиречья; изделия из дерева, железа, стали, волоса, кожи, их недостатки и выгодные стороны; орудия и механизмы, употребляемые кустарями; карты области с нанесением на нее пунктов, где процветает в особенности какая-либо отрасль кустарной промышленности; карты области с нанесением на ней всех промышленных заведений; образцы продуктов заводской промышленности [6, л. 13].

Археологический отдел был незначительным и содержал памятники старины (в их настоящем виде и по фотографическим снимкам), расположенные, если возможно, по историческим периодам, установленным археологией; археологическую карту области с нанесением на нее памятников старины [6, л. 14].

Начиная с 1898 г. и в последующие годы экспонаты музея пополнялись в основном за счет пожертвований частных лиц, уездных начальников, учебных заведений, местных и центральных учреждений. Значимость формируемых музейных коллекций и экспозиций оценивалась в регионе весьма высоко. В письме одного из активных организаторов музея А. И. Иванова от 22 ноября 1907 г. известному в Семиреченском крае купцу Н.Я. Пугасову отмечалось: «Несколько лет назад статистическим комитетом преступлено к устройству областного музея, с научною при нем библиотекой, который должен служить, с одной стороны, наглядным показателем всех естественно-исторических богатств области, сельского хозяйства, промышленности и прочее; с другой - вспомогательным учреждением для лиц, занимающихся изучением прошлого, настоящего и возможно будущего нашего края» [9, л. 24].

Первыми меценатами были члены Семиреченского областного статистического комитета Э.О. Баум и К.А. Ларионов. Они пожертвовали свои личные коллекции. «Первым принесена в дар музею дендрологическая коллекция в количестве 71 экземпляра, а вторым - собранные им в бывшем Кульджинском районе 140 штук птиц, 600 экземпляров насекомых, из коих 200 на булавках и 400 на вате, а также в музей передана была из естественно-исторического кабинета при Верненской мужской гимназии коллекция птиц в количестве 50 чучел» [10, л. 3838об.]. В 1906 г. секретарь комитета В.Е. Недзвецкий писал: «Из членов комитета изъявил пока согласие сотрудничать один Е. Трусов. В 1905 г. им присланы в музей собранные около города Лепсинска растения и бабочки, а также несколько шкурок птиц и зверей, из которых особенно интересна шкура зайца-беляка, не встреченного еще в южной части области, где он заменен монгольским зайцем. В декабре 1905 г. от Трусова получена посылка с рыбами из озера Алаколя. Коллекции дали возможность убедиться, что алакольский окунь, маринка и форель тождественны с балхашскими... Затем изъявил готовность содействовать для музея В. П. Ильиных, от которого получены две шкурки теке - самец и самка. В геологическую коллекцию музея внесли свои вклады образцов вновь найденных полезных ископаемых прежние сотрудники комитета Н. Г. Сатов и Н. Созонтов» $[11$, с. 15]. Немало экспонатов поступало в музей с выставок. В частности, много выставочных предметов было передано в музей с первой сельскохозяйственной и промышленной выставки, устроенной в городе Верном осенью 1902 г.

На устройство музея, лаборатории при нем и на хранение коллекций в разные годы были затрачены различные суммы. Так, в 1905 г. на содержание музея было выделено 432 руб. 24 коп., из которых 150 руб. поступило из городов Пишкепа, Жаркента, Капала, Пржевальска. В течение того же года расход составил 493 рубля 04 коп. [11, л. 21]. Перерасход в 60 руб. 80 коп. вынужден был оплатить заведующий музеем из своей собственной зарплаты. В 1906 г. расходы по музею составили - 109 руб. 3 коп., а в 1907 г. - 290 руб. 9 коп. [10, л. 21]. В среднем на содержание музея ежегодно выделялась суб- 
сидия в размере от 150 до 200 руб. С целью развития и пополнения коллекций музея даже на эти средства члены комитета умудрялись организовывать научные экспедиции.

Богатая в природном отношении Семиреченская область была объектом внимания многих ученых. В 1902-1906 гг. на территории Семиречья с научной целью работали три экспедиции: профессора Томского университета В.В. Сапожникова, Балхашская экспедиция действительного члена Императорского Русского географического общества Л.С. Берга, экспедиция Императорского СанктПетербургского ботанического сада [13, л. 5]. К работе данных экспедиций активно привлекали студентов университетов Томска и Санкт-Петербурга. Успехи экспедиции В.В. Сапожникова в Семиречье, несомненно, заключались в том, что огромную помощь в ее реализации сыграли члены Семиреченского областного статистического комитета, в частности В.Е. Недзвецкий. Результатом двух крупнейших экспедиций профессора В.В. Сапожникова в 1902 и 1904 гг. в Семиречье было издание бесценных «Очерков Семиречья» в двух томах. Результатами Балхашской экспедиции стали ценнейшие сведения и экспонаты по геологии, а также фауне и флоре. Большую помощь в работе этих экспедиций оказали члены Семиреченского областного статистического комитета - ветеринарный врач М.В. Куткин и хранитель музея В.Е. Недзвецкий. Следует отметить, что для пополнения музея ценным материалом и оформления отдельных экспонатов привлекались представители коренного населения и учащиеся Верненской мужской гимназии [14, с. 360-392].
Создателей и сотрудников музея интересовали почти все отрасли хозяйственной деятельности в Семиречье [15, с. 55-58]. Организаторы музея оказывали помощь исследователям недр Семиреченской области. Так, в письме В. Е. Недзвецкого, секретаря комитета в 1913 г., директору горного института И. Ф. Шредергу отмечалось: «...узнав от г. Рейнвельда, что музей горного института рассылает геологические коллекции не только низшим и средним, но даже высшим учебным заведениям, я позволю себе обратиться к Вашему превосходительству с покорнейшею просьбою помочь нашему музею удовлетворить насущную и сильно выраженную потребность местного населения в ознакомлении его с горными породами, прислав коллекцию минералов и возможно более разнообразных руд и горных пород, которые составят образовательный фонд горного отдела» [12, л. 154]. Данное взаимодействие существенно расширяло научные связи формирующегося музея.

Таким образом, в ходе анализа выявленных документальных источников удалось реконструировать процесс оформления музея при Семиреченском областном статистическом комитете, который создал основу для изучения естественных, историко-археологических и духовно-культурных богатств области, а также популяризации знаний о ней. Формирование музейных коллекций и оформление экспозиций создавали благоприятную основу для вовлечения научных специалистов извне, тем самым расширяя знания о регионе. Аккумулируя накопленный материал, музей при Семиреченском областном статистическом комитете становился научно-просветительским центром национальной окраины Российской империи.

\section{Библиографический список}

1. Исламова Д. Государственное краеведение и музейное дело в Тобольской губернии во второй половине XIX - начале XX вв. : автореф. дис. ... канд. ист. наук. Челябинск, 2011.

2. Игумнов Е.В. Музеи Сибирских губернских и областных статистических комитетов (вторая половина XIX начало XX вв.) // Sworld: сборник научных трудов. 2006. T. 10, № 3 .

3. Аленова В.А. Историческая наука в российской провинции в конце XIX - начале XX вв. Рязань, 2002.

4. Урашев С.А. Семиреченский областной статистический комитет - первое научное общество на территории края, 1879-1917 гг. Алматы, 2008.

5. Игибаев С.К. Население Семипалатинской области конца XIX века (по данным Первой всеобщей переписи населения Российской империи) // Проблемы истории и историографии национально-освободительных движений в Казахстане XVIII - начало XX вв. Алматы, 1997.
6. Центральный государственный архив Республики Казахстан (ЦГА РК) Ф. 828. Оп. 1. Д. 1.

7. ЦГА РК Ф. 828. Оп. 1. Д. 2.

8. Отчет по Семиреченскому областному статистическому комитету за 1905 г. Верный, 1906.

9. ЦГА РК Ф. 828. Оп. 1. Д. 3.

10. ЦГА РК Ф. 828. Оп. 1. Д. 5.

11. ЦГА РК Ф. 44. Оп. 1. Д. 484.

12. ЦГА РК Ф. 828. Оп. 1. Д. 6.

13. ЦГА РК Ф. 828. Оп. 1. Д. 4.

14. История Казахстана и России в документах: Прииртышье и Приобье в XVIII - начале XX в. : сборник документов. Барнаул ; Павлодар, 2013.

15. Сабирова Ы.Б. Некоторые вопросы материальной и духовной культуры славянского населения Чуйской долины Семиреченской области Туркестанского края // Проблемы современной науки и образования. 2016. №11 (53). 